\title{
CYCLES OF SOLAR ACTIVITY AS A BASIS FOR FORECASTING THE QUALITY OF DNIEPER WATER
}

\author{
O. Kulishenko ${ }^{1}$, N. Klymenko ${ }^{1}$ \\ ${ }^{1}$ Institute of Colloid and Water Chemistry of the NAS of Ukraine, Kyiv, kullish@gmail.com
}

DOI: https://doi.org/10.20535/2218-930022021236500

One of the main features of the quality of the Dnieper water is the content of natural organic substances which determine the water oxidizability and color indexes. A special problem is that organic substances are poorly removed by water treatment plants. A significant problem in the operation of water treatment plants is the unpredictability of annual changes in the quality of Dnieper water, which complicates logistics management, for example, the supply of reagents. Many years of experience related to the Dnieper water supply station in Kyiv (DnWS) have led to the hypothesis that these changes are in some way related to the cycles of solar activity.

The purpose of this work is to test this hypothesis to substantiate the possibility of predicting the quality of Dnieper water depending on the action of such a global factor as solar activity. The work was performed by statistical methods using 60-year results of Dnieper water analyzes provided by the DnWS laboratory, as well as Wolf numbers (Sunspot Numbers) provided for free use by the Royal Observatory of Belgium. The influence of solar activity on the quality indicators of Dnieper water, especially in its peak and post-peak periods, has been statistically confirmed. The interaction of biological and physicochemical parameters as factors influencing water quality is shown.

As a result of the construction of six reservoirs in 1931-1976, the Dnieper from the river actually turned into a network of water bodies. Now these reservoirs are a kind of reactors in which water is treated by electromagnetic solar radiation, which leads to the cyclic transformation of phytoplankton and natural organic matter. Taking into account the cycles of solar activity, the logistical planning of the operation of water treatment facilities receives an independent "base", changes in which can be predicted with some reliability for years to come.

Keywords: Dnieper water, long-term changes, organic substances, phytoplankton, solar activity

\section{Introduction}

The characteristic feature of Dnieper Basin Rivers is a high content of natural organic matter (NOM), the qualitative and quantitative composition of which largely depends on the season of the year and geoclimatic conditions. In certain periods this content in terms of the total organic carbon (TOC) can reach $18-19 \mathrm{mg} / \mathrm{dm}^{3}$. As shown by Linnik et al. (2013), the NOM concentration in surface water of Ukraine varies over a wide range (from 1.2 to 126.5 $\mathrm{mg} / \mathrm{dm}^{3}$ ) owing to different sources of its formation. A considerable amount of humic substances (HS) in such water is stipulated by the surface slope runoff from marshland. Fulvic acids constitute a major part of HS, and their content can be as high as 80.8$94.8 \%$. The HS content is often estimated by using the water color index $(\mathrm{Clr})$ that can be determined using the simulation dichromate- 
cobalt scale. Examples of seasonal changes in the quality of Dnieper water are presented by Kulishenko et al. (2011).

A significant NOM content in drinking water supply sources is a key factor affecting the water quality and stipulates the use of multiprocess and multistage technologies in water conditioning and purification. Generally, the purification of the Dnieper water implies the use of primary chlorination, coagulation with flocculation, settling and filtering. Prior to the water supply to city it is again chlorinated. Refinement of this technology involved only changes of reagent types and operating regimes of water treatment works. However, the modern reagents and technological procedures do not allow purifying reliably the Dnieper water and maintaining the standard level of $\mathrm{Cl}$ and permanganate oxidizability (PO) in drinking water.

Operational unpredictability of such water purification system over the years is another negative feature that complicates the scheduling of supplies of reagents and preparation of water conditioning and purification stations for future seasons. The conclusions of technological tests performed during certain years may prove to be unacceptable for the other years. Water purification system depends on the interaction of a large number of natural and technological factors. In fact, this system operates under the "manual control".

There are grounds to believe that seasonal and long-term changes of the surface water quality that materially affect technological aspects of its conditioning are stipulated to a certain degree by natural phenomena related to the transfer of solar energy in the earth environment. The topic of the Sun impact on the earth climate, epidemics, and even social phenomena was defined long ago by (Chizhevsky, 1995; Gray et al., 2010). It has gained momentum and now provides massive information regarding correlations between the solar activity (SA) and natural phenomena such as temperature, precipitation, droughts, etc. These relations are very complex. Moreover, the background effects are imposed on them that are related to seasonal changes, intensity of the geomagnetic field, the electromagnetic contamination of the environment and other factors. In addition, in accordance with Alexander et al. (2007), the movement of the Earth around the Sun combined with the movement of other planets along the trajectory of the center of mass of the Solar System through the galactic space affects the earth climate.

The SA impact on precipitations is presented particularly broadly in media sources. Hence, Nazari-Sharabian and Karakouzian (2020) performed the wavelet analysis of hydrometeorological data over 9 regions of Iran during the period of 1950 2018 and established the (8-12)-year cyclicity of atmospheric precipitation, the maximum of which was observed in 1-3 years after the SA peaks. A similar study of Li et al. (2017) based on the wavelet analysis investigated data from 9 meteorological stations located at the plateau in the Yanan region (China) during the period of 1951-2015. In this case, a significant correlation between SA and extreme precipitation was determined. It should be noted that the maximums of the latter occurred during the SA peaks. Gachari et al. (2014) examined the correlation 
between the monthly precipitation in Kenia, position of the Sun and Moon and the number of sunspots during the period from 1901 to the present. As was established in their paper, the extraordinary hydrological events occurred every $5 \pm 2$ years after the turning points of 11-year SA cycles.

Determining the SA impact on the Amazon hydrology by using the proxy recordings of the oxygen isotope content in wood rings, Baker et al. (2018) extended the range of data on the amount of precipitation till 1799. Hence, contradictory results were obtained: correlation coefficients between the oxygen isotopes and the number of sunspots up to the beginning of the 1900s were negative $(r=-0.30$ and -0.50$)$, while in the $\mathrm{XX}$-th century they became positive $(\mathrm{r}=$ 0.60). It raises doubts in authors regarding the connection between SA and precipitation though such contradictions can be adequately explained by the global changes of ecology on a boundary of centuries.

In estimating the impacts of SA on precipitation, droughts and hydrology of water bodies in the Southern Africa beginning from cycle № 14 (1902-1914) Alexander et al. (2007) employ two variable "half-cycles" that make up full (20-22)-year cycles. Every adjacent "half-cycles" correspond to traditional 11-year cycles of SA, but with opposite signs. It is noted that droughts and heavy precipitation occur in periods of minimums and maximums of sunspots, respectively.

The paper of Dong et al. (2018) considers the SA impact on regional precipitation and the discharge of the Yoshino
River (Japan) through the mediation of the El Nino phenomenon. By performing the wavelet analysis, the authors established that El Nino transforms the solar energy into rainfall during the 22-year period, and the impact on the annual flow displays itself with the periodicity of 7 and 11 years.

The modern investigations (Svensmark and Friis-Christensen, 1997; Perry, 2007; Tsiropoula, 2003) also include the galactic cosmic rays that interact with SA by ionizing the atmosphere, increasing the cloud formation and causing the tropospheric and stratospheric fluctuations with periodicity of 10-12 years. These factors affect the hydrology of rivers through such intermediaries as ocean currents. In such a case, the delay times between SA changes and hydroclimatic reaction may reach decades. Hence, besides the known 11-year SA cycle, there are reported 22-year Hale cycle, (8090)-year Gleissberg cycle and others.

The above examples enable us to estimate how broad is the geography of research studies that result in close results in assessing the SA impact on climate. However, despite a considerable amount of studies that interlink SA with hydrological indicators, the impact of this global factor on water quality is actually ignored. The paper of Shevchenko (2011) is one of exclusions, where according to data of the period 1939-2005 the cyclic nature of changes of water quality indicators of the Velikii Aktri Glacier in Altai due to the SA impact on the aerosol precipitation was investigated. Similar relationships were noted for the Ilmen Lake inflow from the Kokshi and Artibash Rivers. 


\section{Objects and methods}

As can be seen from the brief overview above, in recent years the impact of SA cyclic changes on climatic aspects and condition of aqueous ecosystems has been actively studied. However, the study of SA impact on traditional indicators of water quality is practically non-existent. That is why, the purpose of this study is to determine potential changes of physicochemical and biological indicators of the Dnieper water quality related to the NOM content for substantiating the possibility of predicting the water purification efficiency depending on the impact of such global factor as solar activity.
This study makes use of the results of Dnieper water analyses during the periods of 1950-1962, 1996-2006 and 2012-2020 that were provided by the laboratory of the Dnieper water supply station (DnWS) in Kyiv. The specified periods are compared with the solar activity cycles №№ 19, 23 and 24 (Fig. 1). The years and months with the minimum sunspot numbers are adopted as the beginning (end) of these cycles. The sunspot numbers are determined in terms of the Wolf numbers (W) provided for free use by the Royal Observatory of Belgium (http://sidc.oma.be.)

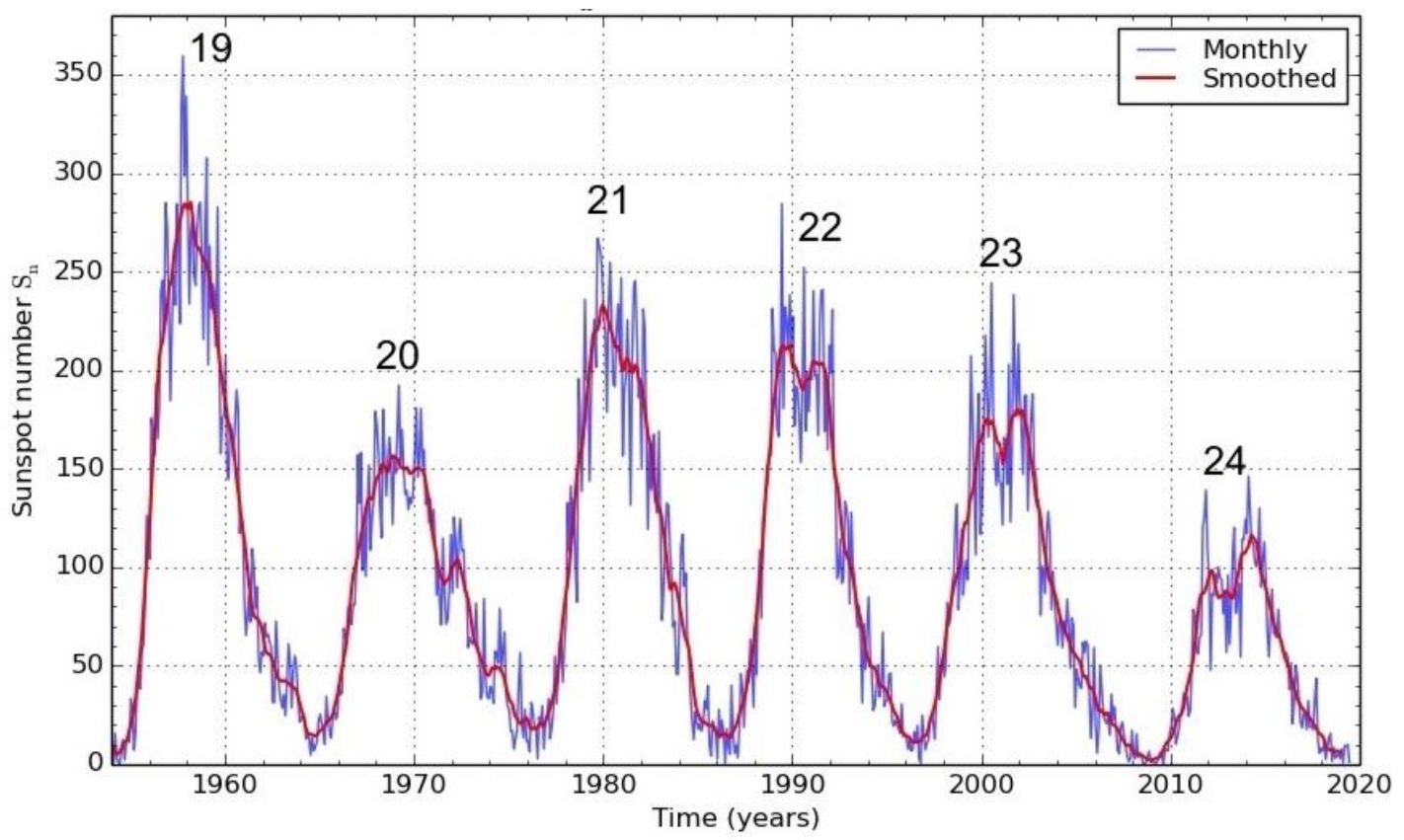

Fig. 1. Dynamics of the Wolf number (sunspot number $S_{n}$ ) variation during the test period

Statistical analysis of data and its graphic interpretation were performed using the Microsoft Excel Tools with calculations of the dynamics series correlations. The estimation of interaction of factors was performed using the Pearson correlation coefficient $r$, and the curve correspondence to a trend was performed using the R-squared determination coefficient $\left(R^{2}\right)$. In this case, even at small values of $r$ and $R^{2}$ we could observe the repeatability and change trends of indicators, because they were greatly affected by powerful extraneous (earth) factors including seasonal changes.

At separate stages of our study we carried out the wavelet analysis of data using 
the software program Cwtld provided for free use by its developer (http://morlet.narod.ru/). The Gauss wavelet was adopted as a basic one. The wavelet analysis is widespread in

\section{Results and discussion}

According to the current classification, the Dnieper water belongs to the class of lowturbidity waters with medium color index. However, in separate year seasons the Dnieper water quality goes far outside the normative limits. The periods of spring rise of the manganese content, spring-summer growth of oxidizability and summer algal bloom are the most troubled periods. $\mathrm{Clr}$ and PO indicators are determined by humic and fulvic acids, their complex compounds with iron. The existing technology of water purification makes it possible to remove larger part of these NOM, however the purified water contains hydrophilic fraction of crenic fulvic acids with small molecular weight featuring a high biochemical stability. It is this fraction that determines the residue values of $\mathrm{Clr}$ and $\mathrm{PO}$ representing one of the main problems of water purification.

Figure $2 a$ presents an example of $\mathrm{Clr}$ and PO changes of the Dnieper water during year 2013. If this plot is continued to previous and next years, it will assume the form of a typical time series (Fig. 2b). Based on longterm changes, polynomial trend curve 2 current climatic and other studies and is common in literature, for example, in Polikar (1995).

appears, with respect to which $\mathrm{Clr}$ seasonal fluctuations occur. The character and amplitude of these fluctuations change every year, and it demonstrates the cyclic nature with maximums in 2013 and 2018 and the minimum in 2015.

Changes of the Dnieper Clr are shown in Fig. $2 b$ against the background of changes of Wolf numbers (W) (curve of trend 1) that characterize the solar activity. The latter represents a complex of physical processes occurring on the Sun and directly linked with the appearance and destruction of strong magnetic fields in the earth atmosphere. The convective mechanism of solar substance transfer originates the self-excited oscillations, half-periods of which having duration of about 11 years manifest themselves at the Sun surface through the sunspots. The number and area of the latter are used to determine the Wolf numbers. The reduction of $\mathrm{Clr}$ designated by arrow is observed about 1.5 years after the SA peak (Fig. 2b). Similar graphs were obtained for cycles SA №oo 19 and 23 (see Fig. 1). 


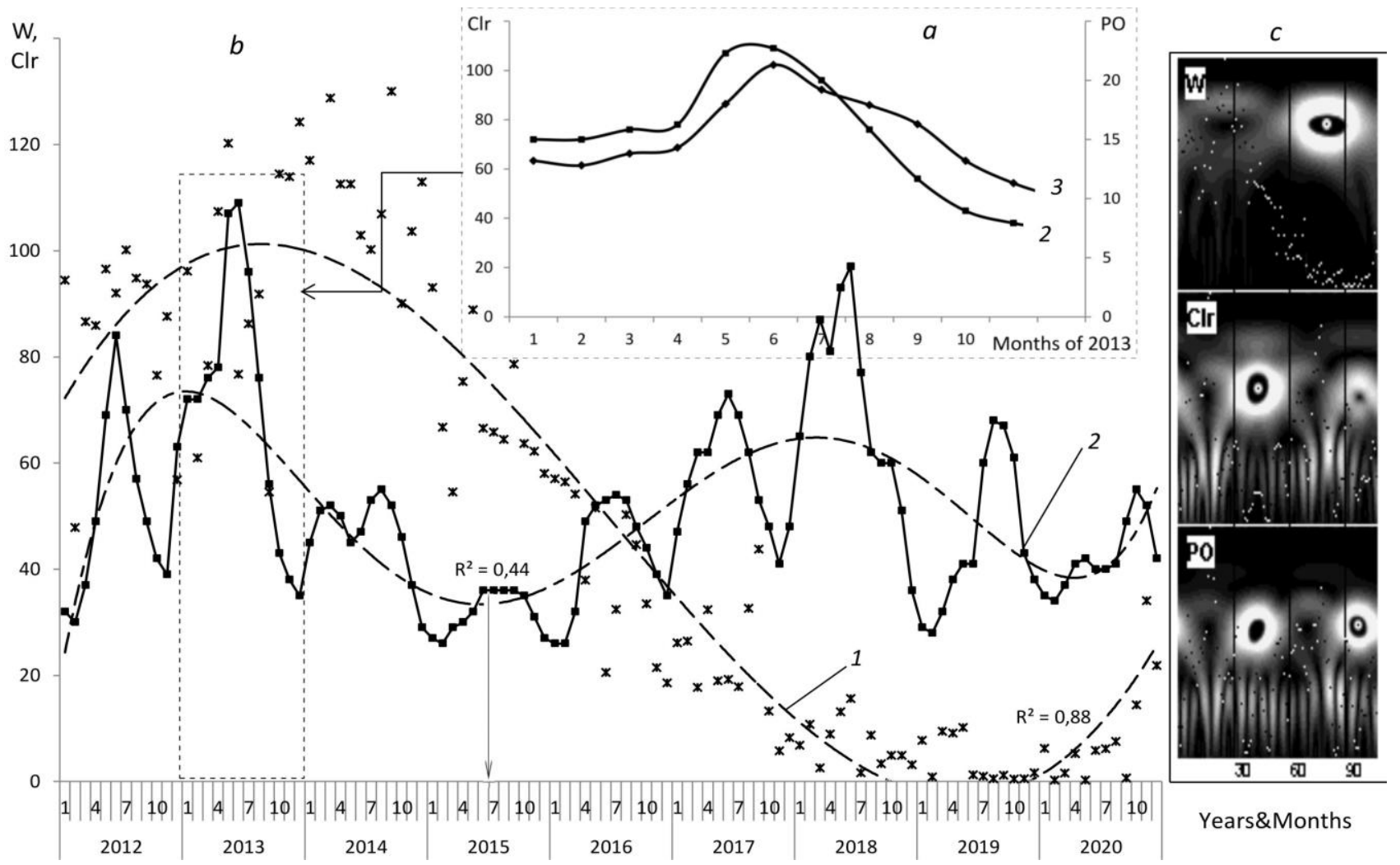

Fig. 2. Changes of W (1), Clr (2) and PO (3) of the Dnieper water in year 2013 (a) and 2012-2020 [(b) and (c)]

Figure $2 c$ displays the wavelet spectrograms obtained by using the software program Cwtld for the same period. The Gauss wavelet was adopted as a basic one for all three indicators (W, Clr and PO). The real time (in months) of the corresponding dynamics series is plotted on the horizontal axis of spectrograms, while the scale as a reciprocal quantity of the fluctuation frequency of indicators is laid off along the Y-axis. In high-contrast monochrome image, minimums of the latter appear as circular and elliptical zones. Small "waves" at the bottom of spectrograms reflect local high-frequency fluctuations.

It should be noted that minimums of $\mathrm{Clr}$ and $\mathrm{PO}$ at spectrograms (Fig. 2c) are about one year apart from $\mathrm{W}$ maximum. The second reduction of these indicators occurs at the beginning of the new 25 -th cycle with the rise of SA. It is of interest that indicators SA (W) and water quality can be simulated by using the same Gaussian basic wavelet, i.e., the character of their changes is similar. Based on this character we can assume that a delayed impact of one of factors (W) on the other (Clr and PO) takes place. The estimation of this delayed impact involved the use of the analysis that consisted in calculation of correlation coefficients $r$ while shifting the dynamics series by specific time lag with respect to one another. Fig. 3 illustrates the changes of $r$ for the Wolf numbers and annual average indicators of $\mathrm{Clr}$ and $\mathrm{PO}$ obtained under the specified shift. With one year lag the correlation coefficients $r$ increase (with sign "-“) to moderate and strong levels. 


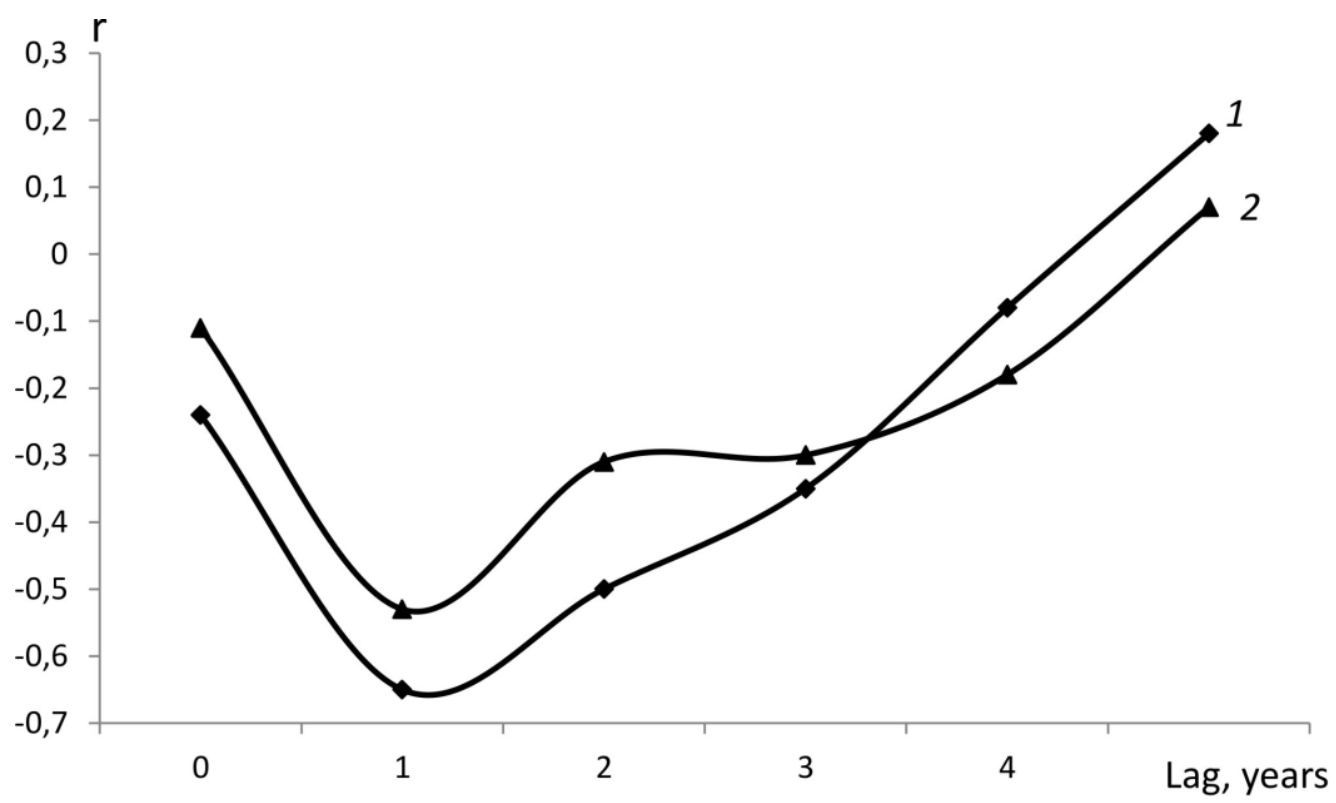

Fig. 3. Changes of estimated coefficients of correlation $r$ in case of shifting the series of Clr (1) and PO (2) with respect to $W$ for $S A$ cycle № 24

Such effect of enhanced correlations with time can be better understood by taking into account a certain "inertia" of natural phenomena as intermediaries in transfer of solar energy in the earth environment. Figure $4 a$ shows the repeatability of this effect for annual average PO indicator on the basis of data from three SA cycles №oo 19, 23 and 24. During the last cycles (№№ 23 and 24), with an increase of $\mathrm{W}$, the oxidizability indicator increases, while in 1-2 years after the SA peak, we observe the PO minimum designated by arrow. Further on, PO again increases. The plot of PO changes is somewhat different in comparison with cycle № 19 that chronologically occurred before the formation of the Dnieper Reservoir. Oxidizability can be replaced with the other factor (Clr or total iron), however the dynamics remains similar.
Figure $4 b$ presents the wavelet spectrograms for average monthly indicators of water color (Clr) and turbidity (Trb). As can be seen from spectrograms, if an SA peak, e.g., for cycle № 23, falls upon the 60th month, the Clr minimum falls upon the interval between the 60-th and 90-th months (+1-1.5 years). Trb minimums are located after the Clr minimums and stretched in time in the interval between the 80th and 110th months (+2-4 years). At first glance, this data unambiguously indicates that the SA impact on the Dnieper water quality is executed through climatic factors. In other words, changes of PO, Clr, Trb and other indicators occur depending on the amount of precipitation and water discharge in the Dnieper River. However, the examination of biological indicators does not allow us to limit the analysis with this explanation. 


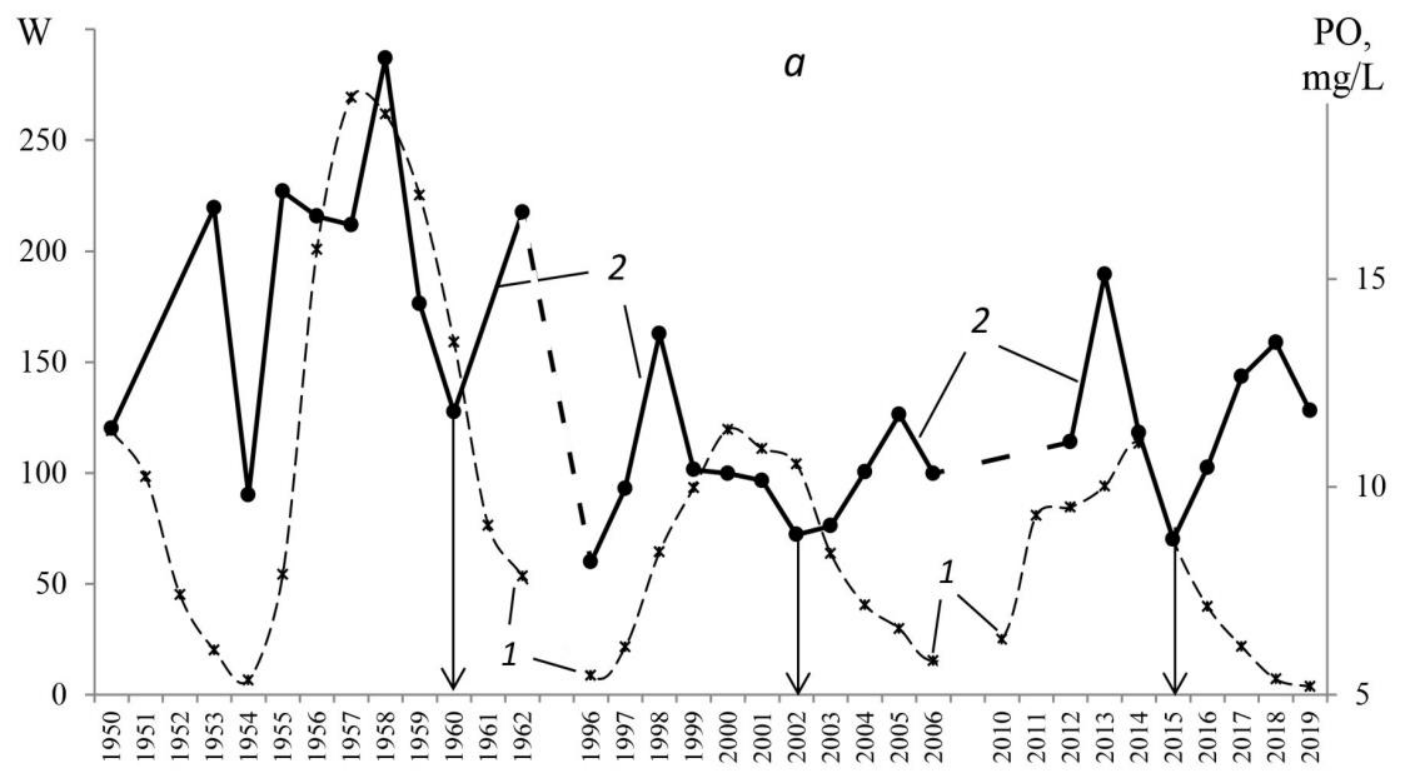

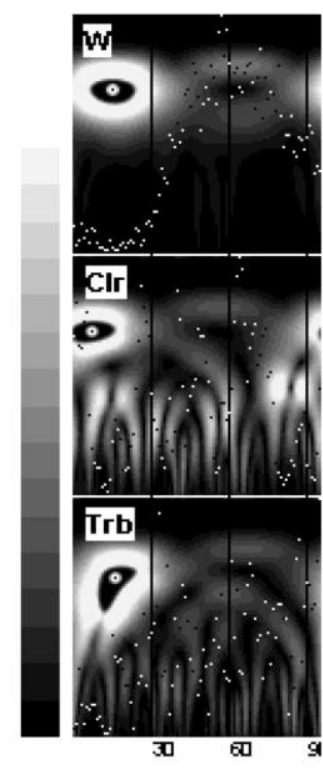

Cycle № 19

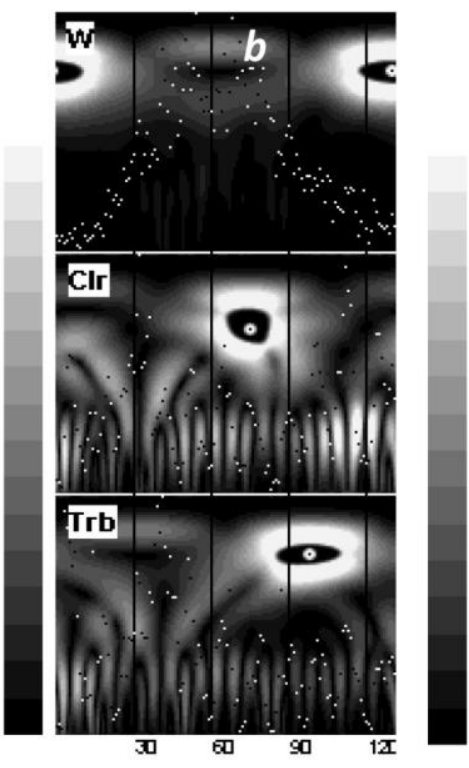

Cycle № 23
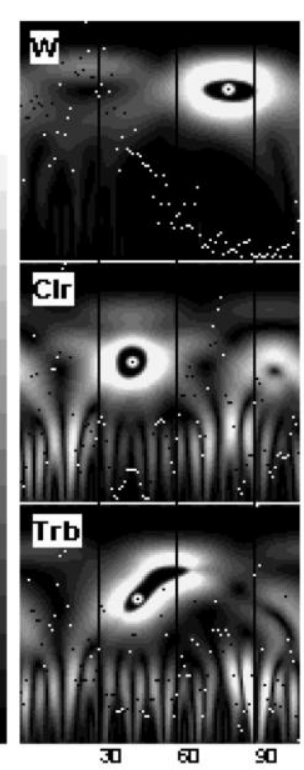

Cycle № 24

Fig. 4. Dynamics of the average annual changes of Wolf numbers $W(1)$ and $P O(2)(a)$ and wavelet spectrograms of average monthly values of $W$, water color $(\mathrm{Clr})$ and turbidity $(\mathrm{Tr} b)(b)$ of the

Dnieper water during SA cycles №№ 19, 23 and 24

It should be noted that in our case the question is not about the river, but about the network of water bodies, into which the Dnieper was transformed owing to the formation of six water reservoirs in 19311976. The modern ecologists and hydrochemists (Khilchevsky et al., 2012; Jacyk and Shmakov, 1992) consider this river just in such context. The scale of these artificial water reservoirs can be imagined from a fragment of Carport's map presented in Fig. 5. 


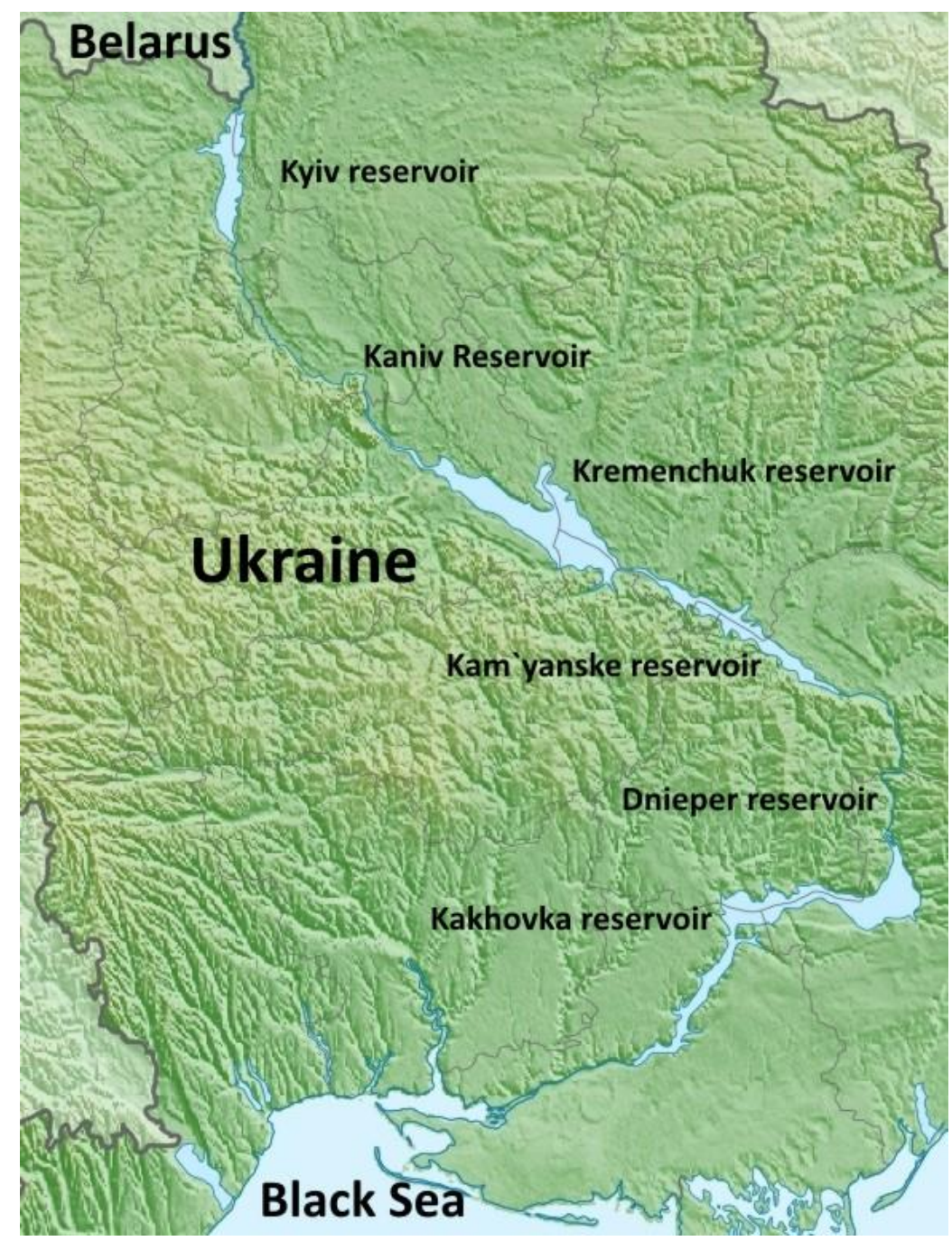

Fig. 5. Dnieper Reservoirs

The Dnieper reservoirs contain about 44 $\mathrm{km}^{3}$ of water at the annual discharge of 46-49 $\mathrm{km}^{3}$, i.e., the complete water renewal in the Dnieper occurs almost within a year. In separate reservoirs, the water exchange takes place from 2 to 20 times a year. The average water velocities in the Dnieper after formation of water reservoirs reduced from 44-77 to $1.7-2.1 \mathrm{~cm} / \mathrm{s}$. These factors did not affect the mineralization and ionic composition of the Dnieper water to such a degree as they enhanced the role of biological processes in ecological system of the Dnieper and led to hyperproduction of blue-green algae.

The impact of SA on algae is considered in literature with sufficient detail.
For example, according to data from paper of Bondarenko and Evstafiev (2006), the development of the Baikal phytoplankton population proceeds in wavily manner. The main "waves" have the period of 22 years (two fragments of 10-11 years, each), the other "standing waves" have period from 3-4 to 6-8 years. The authors explain this phenomenon in terms of the circulation of energy accumulated in NOM. 
Kuzmich (2014) considers the correlations between the amount of phytoplankton in the Dnieper water, solar radiation and the amount of precipitation in the period of 2006-2011. According to his paper, there are no two years alike, however in year 2010 we can observe the correlations of algae amount not only with climatic factors, but also with $\mathrm{Clr}(\mathrm{r}=-0.72)$ and oxidizability $(\mathrm{r}=-0.78)$ of water that

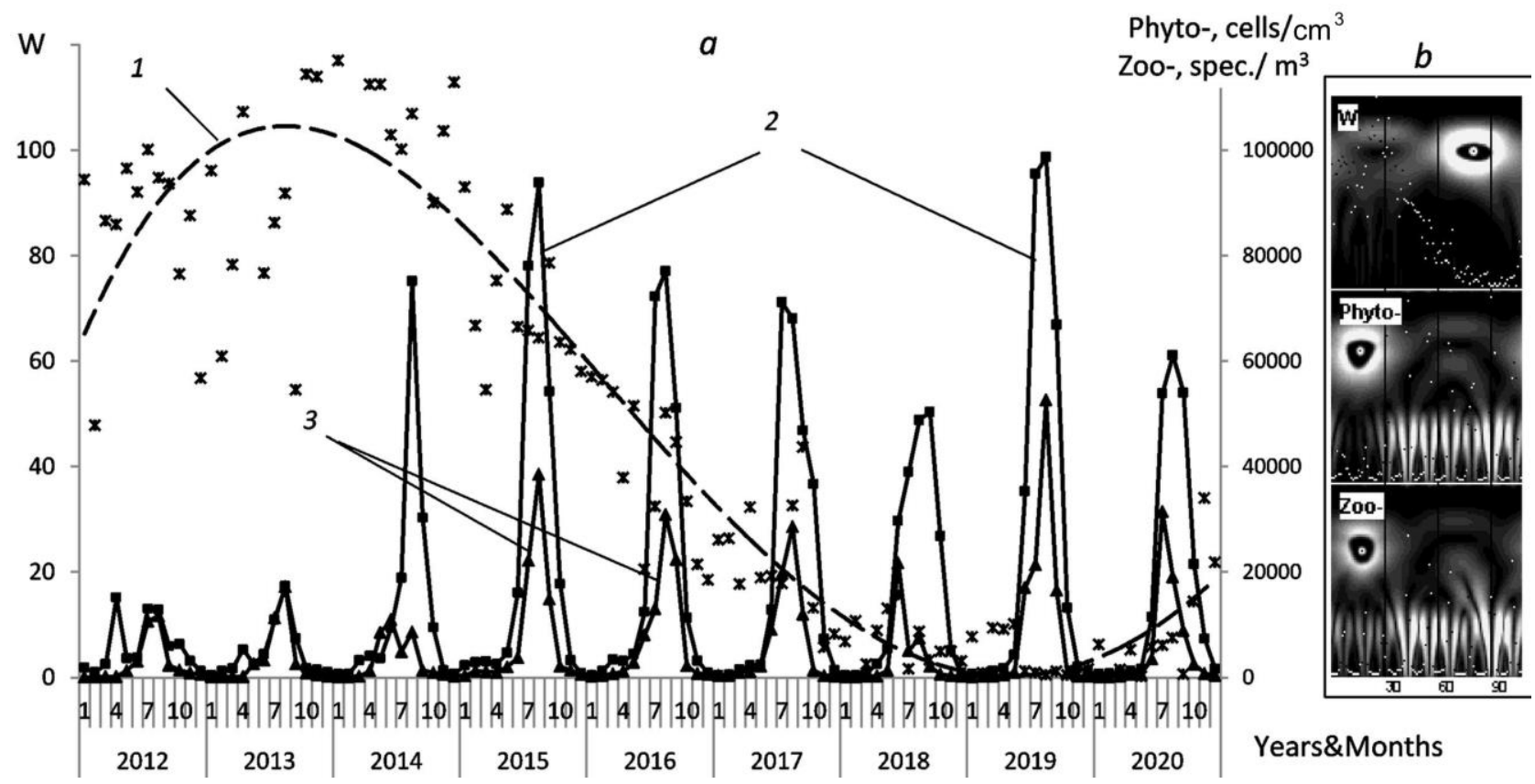

Fig. 6. Changes of $W(1)$, the amount of phytoplankton (2) and zooplankton (3) during SA cycle № 24: dynamics series (a) and wavelet spectrograms (b)

In this case, similar to other cases, a major reduction of plankton amount in water falls upon the period of increasing values of W. It coincides in time with the rise of $\mathrm{Clr}$ and other indicators related to NOM (see Fig. 2). In 1-2 years after passing the SA peak, the amount of phyto- and zooplankton is restored, while the indicators related to NOM reduce.

Figure $6 b$ presents the corresponding results of wavelet analysis of this data that confirm the above specified. Zones of minimums for the amount of phyto- and zooplankton actually coincide in time with the occurrence of $\mathrm{W}$ maximum. After passing the decrease with the increase of phytoplankton amount that is a well-known phenomenon.

Thus, the search for links between the Dnieper water quality and solar activity is not complete without due regard for biological factors, including the blooming of water. Figure $6 a$ shows an example of changes of average monthly amount of phyto- and zooplankton during the last SA cycle № 24 . 
produces moderate-strong effect on changes of Clr, total organic carbon (TOC) and PO also with sign "-“. After 2-4 years more, we can observe the SA moderate-strong effect on zooplankton, phytoplankton and total bacterial count (TBC) with sign “+”. However, the correlation between $\mathrm{W}$ and biological oxygen demand (BOD) achieves the highest level. At the beginning this indicator directly and strongly reacts to SA changes (sign "+") and later it reacts with delay by 3-5 years with sign “.”. It should be remembered that BOD is an indicator of vital activity of aerobic bacteria.

Table 1. Coefficients of correlation between $W$ and main factors

\begin{tabular}{|l|l|l|l|l|l|l|}
\hline \multirow{2}{*}{$\begin{array}{l}\text { Indicators } \\
\text { (factors) }\end{array}$} & \multicolumn{5}{|l|}{ Correlation coefficients $r$ with W, while shifting of years } \\
\cline { 2 - 7 } & 0 & +1 & +2 & +3 & +4 & +5 \\
\hline Clr & -0.24 & -0.65 & -0.50 & -0.35 & -0.08 & 0.18 \\
\hline TOC & -0.40 & -0.77 & -0.44 & 0.02 & 0.20 & 0.36 \\
\hline PO & -0.11 & -0.53 & -0.31 & -0.30 & -0.18 & 0.07 \\
\hline BOD & 0.85 & 0.57 & -0.40 & -0.75 & -0.87 & -0.91 \\
\hline Phytoplankton & -0.60 & -0.17 & 0.45 & 0.89 & 0.88 & 0.64 \\
\hline Zooplankton & -0.39 & 0.14 & 0.67 & 0.72 & 0.60 & 0.41 \\
\hline TBC & 0.07 & 0.30 & 0.52 & 0.16 & -0.03 & 0.08 \\
\hline
\end{tabular}

The joint analysis of correlation coefficients from Table 1 and plots of dynamics series of average annual indicators allows us to propose a dynamic model presented in Fig. 7. This model draws attention to the following sequence of SA action on the selected factors (indicators).

The primary biological product of the ecosystem of water reservoirs constitutes algae that are producers of NOM from inorganic substances. At present, the dominant link in the Dnieper water biocenosis occupy blue-green algae that dictate changes of other indicators. As can be seen from Fig. 7, during the peak of $\mathrm{W}$ in 2013-2014 we can observe a significant reduction of the amount of phytoplankton and zooplankton. In 1-1.5 years, the amount of phyto- and zooplankton increase to maximum, however, the levels of water color index and water oxidizability reduced to minimum. Thus, during the SA peaks we observe massive die-away of algae that contribute to the rise of NOM amount in water and the total bacterial count that, in turn, mineralize the organic residues creating nutrients for new development of algae. With the SA decay, the revival of algae occurred that resulted in consumption of organic matter and reduction of water quality indicators $(\mathrm{Clr}$, TOC, PO, etc.) being derivatives of the organic matter. 


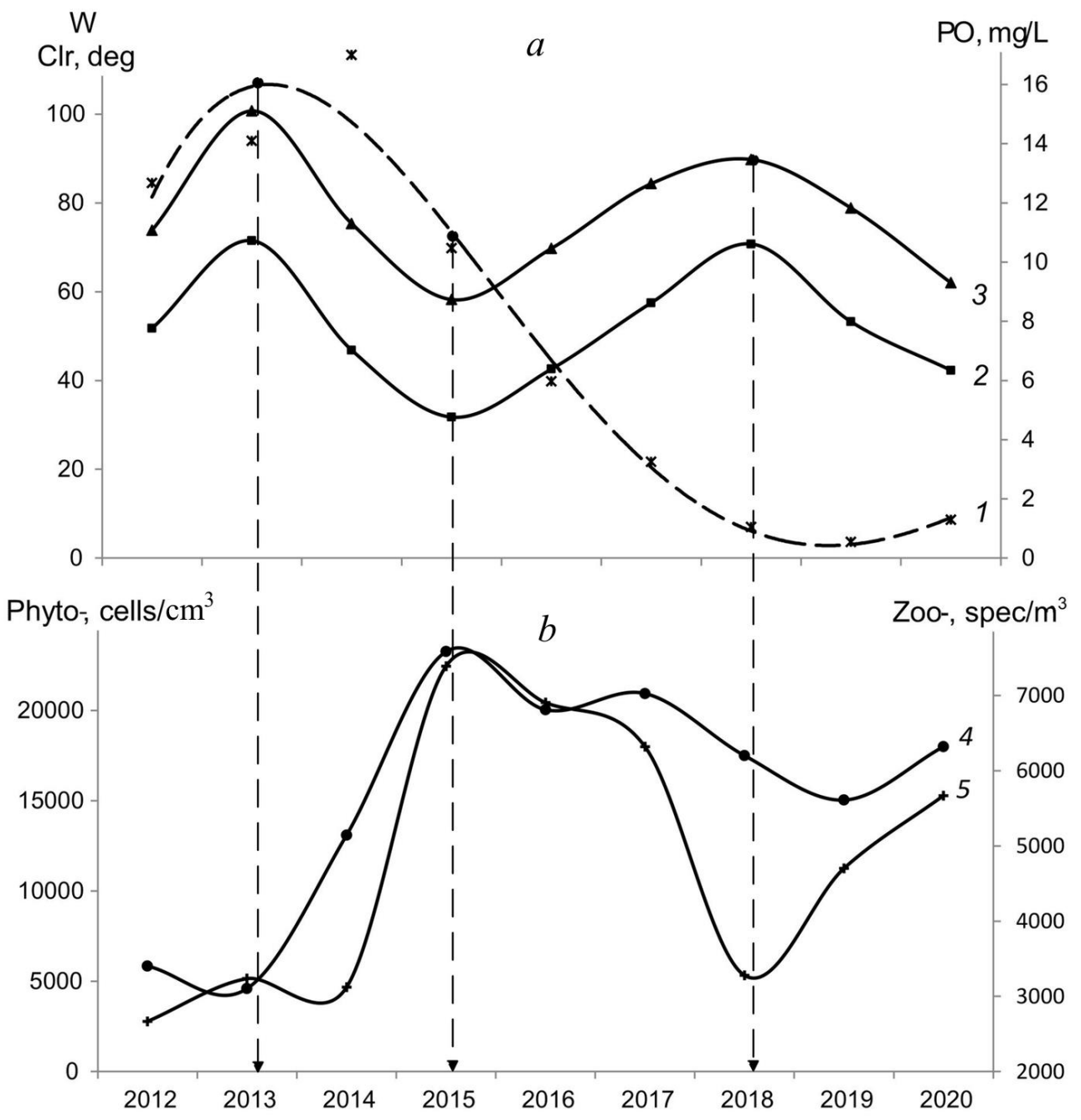

Fig. 7. Average annual changes of W(1), Clr (2) and PO (3) (a) and the amount of phytoplankton (4) and zooplankton (5) (b) over SA cycle № 24

\section{Conclusions}

The Dnieper Reservoirs are a kind of reactors where water is subjected to external processing by the electromagnetic solar irradiation that is strengthened during the peaks of solar activity. It is obvious that we get a complex of influences from the direct action of SA to the delayed effect associated with the presence of water at rest and the development of biological processes therein. In addition, we cannot exclude the impact of precipitation, the amount of which apparently also depends on SA.
The mechanism of electromagnetic action of the Sun on Earth is complex and disguised by the local ("earth") conditions, primarily by climatic and seasonal changes. The model of "standing waves" is the most close to the processes described above. This model implies the cyclic transformation of the phytoplankton content and natural organic substances.

If solar activity is not taken into account, there are doubts in correctness of investigation results when their duration is less than 11 years. Given that solar activity is taken into account, logistical planning of the 
operation of water treatment works obtains a basis in the form of SA cycles, the change character of which can be predicted with specific reliability. For example, as a practical application of such predictions we can schedule the maintenance works on water intake facilities at the period of phytoplankton reduction or on water treatment facilities at the after-peak period of reduction of NOM amount.

\section{Acknowledgements}

This study would not be carried out without assistance of representatives of the Private Joint Stock Company "Kyivvodokanal" in the persons of V.A. Kostiuk, L.P. Avramenko and P.V. Holiuk, who supplied us with complete information and provided methodological assistance in collecting and analyzing the long-term data on the Dnieper water quality in the region of water intake facilities of the Dnieper water supply system in the city of Kyiv.

\section{References}

1. Alexander, W.J.R., Bailey, F., Bredenkamp, D.B., van der Merwe, A., Willemse, N. Linkages between Solar Activity, Climate Predictability and Water Resource Development. J. S. Afr. Inst. Civ. Eng. 2007, 49 (2), 32-44. doi:10.10520/EJC26999.

2. Baker, J.C.A., Gloor, M., Boom, A., Neill, D.A., Cintra, B.B., Clerici, S.J., Brienen, R.J.. Questioning the Influence of Sunspots on Amazon Hydrology: Even a Broken Clock Tells the Right Time Twice a Day. Geophys. Res. Let. 2018, 45, 1419-1422. doi:10.1002/2017GL076889.

3. Bondarenko, N.A., Evstafyev, V.K.. Elevenand Ten-Year Basic Cycles of Lake Baikal Spring Phytoplankton Conformed to Solar Activity Cycles. Hydrobiol. J. 2006, 568, 19-24. doi:10.1007/s10750006-0339-1.

4. Carport. Ukraine Relief Location Map. URL: https://commons.wikimedia.org/wiki/File:Ukraine reli ef location_map.jpg.
5. Chizhevsky, A.L. Earth in the Embrace of the Sun; Moscow: Mysl', 1995 [in Russian].

6. Dong, L., Fu, C., Liu, J., Zhang, P.. Combined Effects of Solar Activity and El Niño on Hydrologic Patterns in the Yoshino River Basin, Japan. Water Resour. Manag. 2018, 32, 2421-2435. doi:10.1007/s11269-018-1937-1.

7. Gachari, F., Mulati, D.M., Mutuku, J.N. Sunspot Numbers: Implications on Eastern African Rainfall. S. Afr. J. Sci. 2014, 110 (1/2), 1-5. doi:10.1590/sajs.2014/20130050.

8. Gray, L.J., Beer, J., Geller, M., Haigh, J.D., Lockwood, M., Matthes, K., Cubasch, U., Fleitmann, D., Harrison, G., Hood, L., Luterbacher, J., Meehl, G. A., Shindell, D., van Geel, B., White, W. Solar Influences on Climate. Rev. Geophys. 2010, 48. doi:10.1029/2009RG000282.

9. Jacyk, A.V., Shmakov, V.M. Hydroecology. Kyiv: Urozhay, 1992. [in Ukrainian].

10. Khilchevsky, V.K., Osadchy, V.I., Kurilo, S.M. Fundamentals of Hydrochemistry. Kyiv: NikaCenter, 2012. [in Ukrainian].

11. Kulishenko, A.Ye., Ostapenko, V.T., Kravchenko T.B., Kvasnitsa, Ye.A., Ostapenko, R.V. Statistical Analysis of Dnieper's Water Indexes and Trends of Water Treatment Plants Reconstruction for the Dnieper Waterworks Station of the City of Kiev. $J$. Water Chem. Technol. 2011, 33 (2), 204-222 [in Russian].

12. Kuzmich, I.S. Correlation Relations that Affect Changes in Water Quality of The Dnieper Cascade and Measures to Solve the Problem. Problems of Water Supply, Drainage and Hydraulics. 2014, 23, 85-97. URL: nbuv.gov.ua/UJRN/PVVG_2014_23 13 (in Ukrainian).

13. Li, H.J., Gao, J.E., Zhang, H.C., Zhang, Y.X., Zhang, Y.Y. Response of Extreme Precipitation to Solar Activity and El Nino Events in Typical Regions of the Loess Plateau. Adv. Meteorol. 2017, 19. doi:10.1155/2017/9823865.

14. Linnik, P.N., Ivanechko, Ya.S., Linnik, R., and Zhezherya, V.A. Humic Substances in Surface Waters of Ukraine. Russ. J. Gen. Chem. 2013, 83, 2715-2730. doi:10.1134/S1070363213130185.

15. Nazari-Sharabian, M., Karakouzian, M. Relationship between Sunspot Numbers and Mean Annual Precipitation: Application of Cross-Wavelet Transform - A Case Study. J. Multidiscip. Sci. 2020, 3, 67-78. doi:10.3390/j3010007. 
16. Perry, C.A. Evidence for a Physical Linkage between Galactic Cosmic Rays and Regional Climate Time Series. Adv. Space Res. 2007, 40 (3), 353-364. doi:10.1016/j.asr.2007.02.079.

17. Polikar, R. The Wavelet Tutorial. The Engineer Ultimate Guide to Wavelet Analysis. 1995. URL: http://users.rowan.edu/ polikar/WTtutorial.html.

18. Shevchenko, G.A. Dependencies of Hydrochemical Factors of Lake Teletskoye and its Influx on Solar Activity. Tomsk State University J. 2011, 344, 204-206. [in Russian].

19. Solar Influences Data Analysis Center (SIDC). URL: http://sidc.oma.be.
20. Svensmark, H., Friis-Christensen, E. Variation of Cosmic Ray Flux and Global Cloud Coverage - a Missing Link in Solar-Climate Relationships. J. Atmos. Sol.-Ter. Phys. (JASTP) 1997, 59 (11), 1225-1232. doi:10.1016/S13646826(97)00001-1.

21. Tsiropoula, G. Signatures of Solar Activity Variability in Meteorological Parameters. J. Atmos. Sol.-Ter. Phys. (JASTP) 2003, 65 (4), 469-482. doi:10.1016/S1364-6826(02)00295-X.

22. Wavelet Analysis with Continuous Wavelet Transform. URL: http://morlet.narod.ru/. 


\title{
ЦИКЛИ СОНЯЧНОї АКТИВНОСТІ ЯК ОСНОВА ДЛЯ ПРОГНОЗУВАННЯ ЯКОСТІ ДНІПРОВСЬКОЇ ВОДИ
}

\author{
О. Кулішенко, Н. Клименко \\ Інститут колоїдної хімії і хімії води НАН України, Київ
}

\begin{abstract}
Однією з характеристик якості дніпровської води є вміст природних органічних речовин, які визначають показники ї̈ окиснюваності та кольоровості. Особливість полягає в тому, щзо ці органічні речовини погано видаляються водоочисними спорудами. Істотною проблемою в роботі водоочисних споруд є непередбачуваність щзорічних змін якості води Дніпра, що ускладнюе логістику, наприклад, постачання реагентів. Багаторічний досвід робіт, пов'язаних з Дніпровською водопровідною станиією м. Києва (ДнВС), привів до гіпотези, щэо ці зміни певним чином пов'язані з циклами сонячної активності.

Метою даної роботи є перевірка цієї гіпотези для обтрунтування можливості прогнозування якості дніпровської води залежно від дії такого глобального чинника, як сонячна активність. Робота виконана статистичними методами з використанням 60-річних результатів аналізів води з Дніпра, наданих лабораторією ДнВС, а також чисел Вольфа (кількості сонячних плям), наданих у вільне використання Королівською обсерваторією Бельгії. Статистично підтверджено вплив сонячної активності на показники якості дніпровської води, особливо в ї̈ піковий та післяпіковий періоди. Показано взаємодію біологічних та фізико-хімічних параметрів як чинників, щьо впливають на якість води.

Внаслідок будівництва шести водосховищ у 1931-1976 рр. Дніпро з річки фактично перетворився на мережу водойм. Зараз изі резервуари є своєрідними реакторами, в яких вода обробляється електромагнітним сонячним опромінюванням, щзо призводить до циклічного перетворення фітопланктону та природної органічної речовини. 3 урахуванням ичиклів сонячної активності логістичне планування роботи водоочисних споруд отримує незалежну "базу", зміни в якій можна з певною достовірністю прогнозувати на довгі роки.
\end{abstract}

Ключові слова: дніпровська вода, тривалі зміни, органічні речовини, фітопланктон, сонячна активність 